\title{
Induced Resistance Against Fusarium Wilt Disease Caused by Fusarium oxysporum in Local Red Peppers (Capsicum annum L.) in Aceh Using Rhizobacteria Isolates
}

\author{
Siti Hafsah1 ${ }^{*}$, Anita Rahayu' ${ }^{1}$, Syamsuddin Syamsuddin', Firdaus Firdaus ${ }^{1}$ \\ Department of Agrotechnology, Faculty of Agriculture, Syiah Kuala University \\ Jl. Hasan Krueng Kalee. Kopelma Darussalam. Banda Aceh 23111 \\ *Corresponding author: sitihafsah@unsyiah.ac.id
}

\section{ARTICLE HISTORY \\ Received : 15 February 2019 \\ Revised : :18 March 2019 \\ Accepted : 28 April 2019}

\section{KEYWORDS}

Rhizobacteria

Resistance

Induction

Local genotypes

Phytopathogen

\begin{abstract}
The ability to develop resistance has been demonstrated by Rhizobacteria in several plant species in order to providing protection against plant pathogen attacks. The use of Rhizobacteria is expected to suppress the attack of Fusarium pathogen in local pepper plants in Aceh. This study is aimed at obtaining information about the important role of Rhizobacterium in inducing the resistance of local pepper plants in Aceh to the attack of Fusarium oxysporum. The research was conducted from March to September 2018 at Seed Science Laboratory and Experimental Garden of the Faculty of Agriculture, Syiah Kuala University. The study used Completely Randomized Design (CRD) Factorial with 2 factors. The first factor was the local peppers (Odeng, Lamando Lapaben, Super Lamando 002 and Lanyoe SS). The second factor was Rhizobacteria isolates (HWI 5 (4) and HWI 8 (6)) which were obtained from the collection of Seed Science Laboratory. The parameters observed: pathogen incubation period, plant height, stem diameter and number of productive branches. The results revealed that the incubation period of $\mathrm{F}$. oxysporum varied in each genotype and type of Rhizobacteria. The application of Rhizobacteria is slowing down the incubation period to 1-3 days in all tested genotypes. Rhizobacteria increased the plants growth especially in HWI 8 (6), characterized by taller plants and larger trunks. The highest interaction between the local genotype of pepper plants and the type of Rhizobacteria was found in the genotypes of Lamando Lapaben and HWI 5 (4) for its number of productive branches.
\end{abstract}

This is an open access article under the CC-BY-SA license.

\section{INTRODUCTION}

Chili or red pepper (Capsicum annum L.) is one of horticultural commodities which have high diversity in their genetics. This plant is belonging to Family Solanaceae and it is an important plant and has been potential to be developed in Indonesia for its economic value. Red pepper is originated in Mexico then it has spread to the regions of South and Central America, Europe and is now widespread in the tropics and subtropics. Guatemala is the secondary distribution center for this commodity (Syukur et al., 2012; Sahu et al, 2018). In Indonesia, production of red peppers was 50.189 tons in 2014, which is increased 7.762 tons compared to 2013. The increase of pepper yield related to an increase in productivity of 0.94 tons/ha and an increase in harvested area of 341 ha (Badan Pusat Statistik, 2015). However, the productivity of red peppers in Indonesia is relatively low compared to its production potential which can reach 20 tons/ha (Duriat et al., 1999). Lower production mostly caused by pests and diseases, such as Fusarium wilt disease caused by Fusarium oxysporum (Musa et al., 2005).

The diversity of Aceh pepper genotypes can be found in Bener Meriah Regency where the plants have been developed and maintained well by the farmers. The dominant genotypes cultivated are genotypes Odeng, Lanyoe, Super Amando and Lamando Lapaben, which have been known for their high productivity and good quality (BPSBTPH, 2015). Unfortunately, these excellent productivity and quality did not guarantee its tolerance to plant diseases. Suyanti (2013) stated that the attack of pests and diseases to pepper plants in Aceh reached up to $22.5 \%$ in 2011.

F. oxysporum is a pathogen that causes wilt disease in pepper plants. This pathogen can attack the plants from germination to mature plants. The presence of $F$. 
oxysporum is one of the limiting factors that cause deterioration in chili or pepper production. Losses due to Fusarium wilt disease in red pepper plants are quite high. Rostini (2011) reported that this disease can cause crop losses and failures of up to $50 \%$.

The use of biological agents against $F$ oxysporum is highly recommended, such as Rizobacteria which also have been proven to trigger induced systemic resistance in plants in order to providing protection to plants against pathogens. This ability needs to be applied to prevent and reduce damage in plants (Komang et al., 2013). This rhizobacteria is recommended to control pathogen $F$. oxysporum in pepper plants.

This study aimed at obtaining information about the induced resistance of the local red pepper genotypes against $F$. oxysporum using rhizobacterial isolates. The benefit of this study was to obtain information on resistance level of local red peppers germplasm collected from Aceh Province after being induced by Rhizobacteria isolates.

\section{MATERIALS AND METHODS}

The research was conducted in March to September 2018. The multiplication and maintenance of $F$. oxysporum were carried out at the Seed Science and Technology Laboratory of the Agrotechnology Department, Syiah Kuala University, Banda Aceh. The materials used laminar air flow, autoclave, Erlenmeyer, Bunsen burner, petri dishes ( $9 \mathrm{~cm}$ in diameter), forceps, borer cock $(0.5 \mathrm{~mm})$, analytical balance, hoes, trays, scissors, measuring tape, plastic cups, hand sprayer, watering cans, staplers, and some utensils.

Red pepper genotypes used in this research were genotypes Odeng, Lamando Lapaben, Super Lamando 002, and "Lanyoe" SS (obtained from Bener Meriah Regency), pure isolates of F. oxysporum and Rizobacteria (obtained from the collection belongs to Laboratory of Seed Science and Technology, Faculty of Agriculture, Syiah Kuala University). PDA media, distilled water, cotton, plastic wrap, fabric bleach, oats, alcohol $70 \%$, distilled water, heat resistant plastics, rubber, paper towels and label and labeling papers.

This research used Completely Randomized Design (CRD) Factorial, divided into 2 experiments. First experiment used CRD Factorial with 2 factors. First factor was red pepper genotypes (G) which consisted genotype Odeng $\left(\mathrm{G}_{1}\right)$, Lamando Lapaben $\left(\mathrm{G}_{2}\right)$, Super Lamando 002 $\left(G_{3}\right)$, dan "Lanyoe"SS $\left(G_{4}\right)$, and second factor was Rhizobacteria isolates (R) consisted HWI 5(4) $\left(R_{1}\right)$ and HWI 8(6) $\left(\mathrm{R}_{2}\right)$ compared to control $\left(\mathrm{R}_{0}\right)$.

\subsection{Preparation of Pepper Seeds and Planting Media}

The 30 days old seedlings have been used in this experiment. The planting medium consists of topsoil and manure mixture of topsoil soil and manure (ratio 2:1). Then, the mixture was put into a polybag $(10 \mathrm{~kg}$.) Preparation of planting media was done a week before transplanting.

\subsection{Inoculation of $F$. oxysporum}

Inoculation of pathogen $F$. oxysporum was carried out through two stages. First, through transplanting process by immersing the root of the treated seed in the fungus substrate and second, the inoculation done on pepper plants 21 days after transplanting by spreading $10 \mathrm{~g}$ of inoculum to the soils around the plants and treated stems (Ibrahim et al., 2014).

\subsection{Seed Transplanting}

12 seeds in each treatment were replaced into $10 \mathrm{~kg}$ polybag (one seed/polybag). For controls, 12 untreated seeds had been sowed to soil which was not inoculated with F oxysporum. The seed replacement was done in the late afternoon to avoid high evaporation. The replacement must be done carefully by pulling the seed grew in media in the hole under the tray and prying the edges. The seeds was put into the planting holes along with the media and covered with soil while pressing the planting media towards the seedling media. The purpose of putting the seeds along with the media was to avoid transplanting shock and to protect the roots from damage. The planting media was a mixture of soil and manure with ratio $2: 1$. The planting media containing the seeds was placed within $30 \mathrm{~cm} \times 50 \mathrm{~cm}$.

NPK fertilizers were applied one week after planting (ratio 16:16:16) with dose $10 \mathrm{~g} / \mathrm{L}$. Each plant received as much as $250 \mathrm{ml}$ of fertilizers. The application of fertilizers was done once a week (Syukur et al., 2017).

\subsection{Plant Maintenance}

Plant maintenance was applied by installing the wooden stakes, watering, replanting and trimming the plants.

\subsection{Observations}

\subsubsection{Incubation Period of $F$. oxysporum}

Incubation period was observed daily until the symptoms of $F$. oxysporum is appeared. This symptom were characterized by yellowing margins of the leaves and then followed by the similar symptoms to younger leaves (Ploetz, 2006). This observation was done a day after application.

\subsubsection{Plant Height}

Plant height was observed from the base of the stem to the highest growing point. The measurement started soon after first harvest or at 90 days after planting.

\subsubsection{Stem diameter}

The measurements of stem diameter were carried out at $15,30,45$ and 60 days after planting by measuring it from the base of the stem.

\subsubsection{Number of Productive Branches}

Productive branches are the main branches where fruit is located. The number of productive branches was observed after first harvest or at 90 days after planting. 


\subsection{Statistical Data Analysis}

Data were subjected to Analysis of Variance (ANOVA) where significant differences existed means were separated using Duncan's Multiple Range Test (DMRT) at 0.05 probability level.

\section{RESULTS AND DISCUSSIONS}

\subsection{Incubation Period of F.oxysporum}

Table 1 indicated that the longest incubation period found in a combination of Super Lamando genotype with rhizobacteria HWI 5(4). The results showed that the application of HWI 5(4) rhizobacterial isolates could induce optimal resistance as indicated by the duration of the symptoms. It can be seen that the longer the incubation period, the weaker the pathogen to multiply.
According to Kim et al. (2008), Rhizobacteria are not only promoting the plant growth, but also they have function as biocontrol agents of various pathogens, such as $F$. oxysporum which causes fusarium wilt in pepper plants.

This ability is related to the ability of rhizobacteria as rhizosphere bacteria which directly produce secondary metabolites such as siderophores, HCN, external enzymes and antibiotic compounds which indirectly enhance the plant growth by inducing plant resistance and inhibiting the colonization of roots by harmful pathogens (Hayat et al, 2010; Shrivastava and Kumar, 2015).

Hoerussalem et al. (2013) also added that the indicator of induced resistance in plants by rhizobacteria against pathogenic infections occurs due to the increased activity of the peroxidase enzyme, phenylalanine ammonia-lase and polyphenol oxidase and the production of phytoalexin compounds.

Table 1. Incubation period of Foxysporum

\begin{tabular}{|c|c|c|c|}
\hline \multirow{3}{*}{ Genotypes } & \multicolumn{3}{|c|}{ Rhizobacteria incubated } \\
\hline & Untreated (without rhizobacteria) & HWI 5(4) & HWI 8(6) \\
\hline & \multicolumn{3}{|c|}{ Incubation period (days) } \\
\hline Odeng & 2.73 & 3.37 & 3.40 \\
\hline Lamando Lapaben & 3.43 & 2.54 & 3.28 \\
\hline Super Lamando & 3.77 & 4.21 & 1.49 \\
\hline Lanyoe & 2.44 & 3.88 & 2.39 \\
\hline
\end{tabular}

\section{2 Plant Height}

Results given in Table 2 revealed that there were no significant differences in the plant height of the four genotypes tested. However, the results showed that the height of plant which its seed treated using HWI 8 (6) rhizobacteria demonstrated the highest height $(41.24 \mathrm{~cm})$ which was significantly different from the other treatments. The seeds treated using rhizobacteria had a positive influence on the height of the plants where the seeds treated with rhizobacteria will possess better growth although the plants have been infected by Fusarium wilt disease.

Table 2. The height of pepper plants

\begin{tabular}{ll}
\hline Genotypes & Plant height $(\mathbf{c m})$ \\
\hline & \\
Odeng & $\mathbf{3 7 . 1 6}$ \\
Lamando Lapaben & $\mathbf{3 3 . 3 3}$ \\
Super Lamando & $\mathbf{3 0 . 2 3}$ \\
Lanyoe & $\mathbf{4 1 . 2 0}$ \\
\hline Rhizobacteria & \\
Untreated (without rhizobacteria) & $30.28 \mathrm{a}$ \\
HWI 5(4) & $35.03 \mathrm{a}$ \\
HWI 8(6) & $41.24 \mathrm{~b}$
\end{tabular}

Means followed by the same letters do not differ significantly ( $\mathrm{P}=0.05$ ) as determined by DMRT test

\subsection{Stem Diameter}

Table 3 represented vegetative growths of genotypes tested indicating the resistance of local pepper plants to Fusarium wilt disease caused by $F$ oxysporum were described by the length of stem diameter days after planting (DAP).

Table 3. Stem diameter of pepper plants

\begin{tabular}{lrrrr}
\hline \multicolumn{1}{c}{ Treatments } & \multicolumn{4}{c}{ Stem diameter $(\mathrm{mm})$} \\
& $15 \mathrm{DAP}$ & $30 \mathrm{DAP}$ & $45 \mathrm{DAP}$ & $60 \mathrm{DAP}$ \\
\hline Odeng & 1.36 & $1.82 \mathrm{a}$ & $2.36 \mathrm{a}$ & $2.85 \mathrm{a}$ \\
Lamando Lapaben & 1.53 & $2.35 \mathrm{a}$ & $3.41 \mathrm{a}$ & $4.15 \mathrm{a}$ \\
Super Lamando & 3.51 & $1.88 \mathrm{a}$ & $2.52 \mathrm{a}$ & $3.16 \mathrm{a}$ \\
Lanyoe & 1.68 & $2.27 \mathrm{a}$ & $3.05 \mathrm{a}$ & $3.39 \mathrm{a}$ \\
\hline
\end{tabular}

Means followed by the same letters do not differ significantly ( $\mathrm{P}=0.05$ ) as determined by DMRT test. DAP = days after planting.

\subsection{Productive Branches}

The results showed that there was a significant interaction between the treatments of rhizobacteria isolates to several genotypes of local red peppers to the number of productive branches. It is described in Table 4. It revealed that the highest number of productive branches was found in a combination of genotype Super Lamando treated with rhizobacteria HWI 8(6) with an average number of productive branches of 24.7 but it was insignificant compared to genotype Lanyoe treated with rhizobacteria HWI 8(6) and genotype Lamando Lapaben treated with rhizobacteria HWI 5 (4) but were significant 
from other combined treatments.

Table 4. The number of productive branches

\begin{tabular}{lccc}
\hline \multirow{2}{*}{ Genotypes } & \multicolumn{3}{c}{ Number of productive branches } \\
\cline { 2 - 4 } & $\begin{array}{c}\text { Untreated } \\
\left(\mathrm{R}_{0}\right)\end{array}$ & HWI 5(4) & HWI 8(6) \\
& $8.25 \mathrm{Aa}$ & $13.92 \mathrm{Aa}$ & $14.78 \mathrm{Aa}$ \\
\hline Odeng $\left(\mathrm{G}_{1}\right)$ & $7.81 \mathrm{Aa}$ & $24.67 \mathrm{Cb}$ & $14.67 \mathrm{Ba}$ \\
Lamando Lapaben $\left(\mathrm{G}_{2}\right)$ & $6.44 \mathrm{Aa}$ & $9.33 \mathrm{Aa}$ & $24.7 \mathrm{Bb}$ \\
Super Lamando $\left(\mathrm{G}_{3}\right)$ & $8.42 \mathrm{Aa}$ & $9.92 \mathrm{Aa}$ & $21.81 \mathrm{Bb}$ \\
Lanyoe $\left(\mathrm{G}_{4}\right)$ & &
\end{tabular}

Means followed by the same letters do not differ significantly ( $\mathrm{P}=0.05)$ as determined by DMRT test.

Relatively, the results showed that the treatment using rhizobacteria HWI 8(6) exhibited more productive branches compared to plants treated with rhizobacteria HWI 5(4) and controls. Table 2 also showed that each genotype had different response to the application of rhizobacteria. For example, the application of rhizobacteria HWI 8 (6) is relatively better in genotype Super Lamando compared to the same type of rhizobacteria treated to other genotypes. This finding is in line with the results of Mardhiah et al. (2016). They have found that the number of productive branches show a different response between PM888 and PM999 pepper varieties to the treatment of indifferent type of rhizobacteria.

The combined treatment $\mathrm{G}_{3} \mathrm{R}_{2}$ demonstrated significant growth of productive branch compared to all untreated genotypes. This finding indicated that the application of rhizobacteria HWI 8(6) to seeds before planting enables infected pepper plants to survive and keep growing. It is in agreement with research of Rosadiah et al (2015). They found that the application of rhizobacteria to pepper seeds before planting (treated with inoculated pathogen) showed the ability to grow, same results when compared to controls (untreated seeds and without pathogenic inoculation). Safriani et al. (2016) also added that Induced Systemic Resistance (ISR) is one mechanism that occurs in plants mediated by these rhizobacteria. Chaudhary et al (2007) also stated that ISR is a form of induced resistance where in plant defenses are preconditioned by prior infection or treatment that results in resistance against subsequent challenge by a pathogen or parasite

\section{Conclusion and Recommendation}

It can be concluded that the application of Rhizobacteria could induce the pepper resistance by slowing down of the incubation period of $F$ oxysporum. Genotype Lamando Lapaben treated with rhizobacteria HWI 8(6) possessed the highest result in stem diameter. The application of rhizobacteria HWI 8(6) also exhibited best results in plant height and diameter. The highest number of productive branches was found in combined treatment. The best combination of treatments on the number of productive branches was found genotype Super Lamando treated with rhizobacteria HWI 8 (6).

The use of rhizobacteria isolates as biocontrol agents in inducing resistance against fusarium wilt disease caused by pathogens $F$. oxysporum in local pepper plants needs to be further investigated such as evaluating the effective density of rhizobacteria to reduce pathogenic infections and it is recommended to evaluate the systemic acquired resistance (SAR) mechanism in the induction of the resistance of pepper plants.

\section{REFERENCES}

Amelia, S. 2017. The ability of Rhizobacteria in inhibiting the growth of seed-borne pathogen and to stimulate the growth of tomato (Lycopersicum esculentum Mill.) plants (written in Indonesian language). Script. Universitas Syiah Kuala, Banda Aceh.

Badan Pusat Statistik Aceh. 2015. Produksi cabai besar, cabai rawit, dan bawang merah tahun 2013. http://www.bps.go.id. [Accessed on 13 February 2017].

BPSBTPH. 2012. Deskripsi Cabai Odeng. www.bpsbtph.acehprov.go.id [Accessed on 10 November 2017].

Chaudhary, D.K., A. Prakash, B.N. Johri. 2007. Induced systemic resistance (ISR) in plants: mechanism of action. Indian Journal of Microbiology 47(4): 289-297.

Handayani, R. S., Yusuf, M., \& Akmal, A. (2018). Potential Changes in Watermelon (Citrullus lannatus) Pbidy Treated By Colchicine. Journal of Tropical Horticulture, 1(1), 10-14.

Hayat, R., S. Ali., U. Amara., R. Khalid and I. Ahmed 2010. Soil beneficial bacteria and their role in plant growth promotion: A review. Annals of Microbiology. 60 (4): 579-598.

Hoerussalam., A. Purwantoro dan A. Khaeruni. 2013. Induced Resistance in corn (Zea Mays L.) against downy mildew disease through seed treatment and its inheritance to S1 generation (written in Indonesian language). Jurnal Ilmu Pertanian. 16(2): 42-59.

Ibrahim, A., S. Ilyas., dan D. Manohara. 2014. Seed treatment using Rhizobacteria in Chili (Capsicum annum) plants to control Phythopthora capsici and to increase seed vigor and plant growth (written in Indonesian language). Bul Agron. 34(2):124-132.

Kim, Y. S., B. Jang., I. M. Chung., M. K. Sang., Ku, HM, Kim, KD \& Chun, SC. 2008. Enhancement of biocontrol activity of antagonistic Chryseobacterium strain KJ1R5 by adding carbon sources against Phytophthora capsici. Plant Pathol. 24: 164-70.

Komang, A. M., K. Khalimi dan G. Ngurah. 2013. The efficacy of Rhizobacteria as antagonistic bacteria against Fusarium oxysporum f.sp capsici causing Fusarium Wilt in cayenne pepper (Capsicum frutencens L.) (written in Indonesian language). E-Jurnal Agroekoteknologi Tropika. 2(3):145-154

Mardhiah., Syamsuddin dan Efendi. 2016. Seed treatment using plant-growth-promoting Rhizobacteria on vegetative growth and yield of red peppers (written in Indonesian language). J. Floratek. 11 (1): $25-35$

Musa, A. S., M Wachjadi, dan L Soesanto. 2005. Potential of several botanical pesticides for land restoration of Chili plantation (written in Indonesian language). In Planta. Universitas Soedirman. Purwokerto

Rosadiah, F. N., S. Ilyas. Dan D. Manohara. 2015. Seed treatment of pepper (Capsicum annum L.) plants using rhizobacteria, singly or in combination to control Phythopthora capsici and to promote plant growth (Capsicum annuum L.) (written in Indonesian language). J. Hort. Indonesia. 6 (1): 1-10. 
Rostini, N. 2011. 6 Jurus Bertanam Cabai Bebas Hama dan Penyakit. PT AgroMedia Pustaka, Jakarta, Hal 41

Safriani., Syamsuddin., dan Marlina. 2016. In-vitro antagonistic activity of growth-inhibiting rhizobacteria to the growth of seed borne pathogens in chili seeds and its effect to seed viability (written in Indonesian language). Jurnal Kawista 1(1):50-58

Sahu, P.S., A. Kumar., H. Husain and H. Naz. 2018. Seasonal incidence of chilli thrips, Scirtothrips dorsalis (Hood)(Thripidae: Thysanoptera): A review. Journal of Entomology and Zoology Studies. 6(1): $1738-1740$

Shrivastava, P and R. Kumar. 2015. Soil salinity: a serious environmental issue and plant growth promoting bacteria as one of the tools for its alleviation. Saudi Journal of Biological Sciences. 22(2): 123-131.

Suyanti K. 2013. Interrelation between products and businessmen in development of horticulture agribusiness in Aceh Province (written in Indonesian language). Jurnal Manajemen dan Agribisnis 10(2): 117-127.

Syukur M., S. Sriani., Y. Rahmi. 2012. Teknik Pemuliaan Tanaman. Penebar Swadaya, Jakarta.

Zahara, M., Hasanah, M., \& Zalianda, R. (2018). Identification of Zingiberaceae as medicinal plants in Gunung Cut Village, Aceh Barat Daya, Indonesia. Journal of Tropical Horticulture, 1(1), 24-28. 